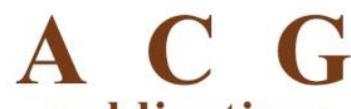

Org. Commun. 12:3 (2019) 169-175

organic

publications

communications

\title{
Synthesis and in vitro activity of oleanane type derivatives against Chlamydia trachomatis
}

\section{Oxana B. Kazakova 1*, Liudmila V. Rubanik@2, Irina E. Smirnova@1, Olga V. Savinova ${ }^{2}$, Anastasiya V. Petrova ${ }^{1}$, Nikolay N. Poleschuk ${ }^{2}$, Elmira F. Khusnutdinova 1 , Eugene I. Boreko ${ }^{2}$ and Yuliya M. Kapustina ${ }^{2}$}

\author{
${ }^{1}$ Ufa Institute of Chemistry of the Ufa Federal Research Centre of the Russian Academy of \\ Sciences, Ufa, 450054, Russian Federation \\ ${ }^{2}$ Republican Research and Practical Center for Epidemiology and Microbiology, Minsk, \\ 220114, Belarus
}

(Received July 29, 2019; Revised August 20, 2019 ; Accepted August 25, 2019)

\begin{abstract}
Modified synthesis of 3ß-nicotinoyloxy-olean-12(13)-en-28-oic acid and 3-deoxy-3a-homo-3a-aza28-hydroxy-olean-12(13)-ene from natural occurring oleanolic acid is suggested. These compounds and two others of ursane and lupane type triterpenoids (3-oximino-urs-12-en-28-oic acid and 3-deoxy-3a-homo-3a-aza28-hydroxy-lup-12(13)-ene) were screened in vitro against Chlamydia trachomatis strain F-3271/Belarus/2015. Oleanane triterpenoids became the leading compounds with chemotherapeutic index $>8$ and were chosen for further research.
\end{abstract}

Keywords: Synthesis; triterpenoids; oleanane; ursane; Chlamydia trachomatis. (C) 2019 ACG Publications. All rights reserved.

\section{Introduction}

Triterpenoids are distributed widely in higher plants and are of interest because of their different types of biological activities. ${ }^{1}$ For example, betulinic acid had a great effect against dysplastic nevus, ${ }^{2}$ betulin is currently in phase III clinical trials for the treatment of burns and for its impregnation into medicinal bandages. ${ }^{3}$ Triterpenoids also exhibit a wide spectrum of antimicrobial activity. Different types of pentacyclic triterpenoids have significant antistaphylococcal activity on at least one strain, and it is postulated that the primary target for their antimicrobial activity is the cell membrane which could also explain one of their other effects. ${ }^{4}$

Chlamydia trachomatis is a common sexually transmitted pathogen that can cause infertility. ${ }^{5}$ This infection is treated with broad-spectrum antibiotics which affect pathogens as well as the

\footnotetext{
* Corresponding author: E-mail: obf@anrb.ru

The article was published by ACG Publications 


\section{Synthesis and in vitro activity of oleanane type derivatives}

normal endogenous microflora. With conventional antibiotic treatments, there is difficulty in achieving the complete eradication of chronic chlamydial infections, the possibility of developing drug resistance, and the unintended creation of other antibiotic-resistant pathogens. For this reason, it is important to consider new compounds exhibiting various means of antimicrobial activity and finding novel non-toxic compounds for the treatment of chlamydial infections remains an important goal. $^{6}$

\section{Background}

The properties of different terpenoids as inhibitors of the bacteria family Chlamydiaceae, particularly C. trachomatis, are poorly studied. For diterpene lactone Andrographolide $\mathrm{IC}_{50}$ values were found to be 46 and $50 \mu \mathrm{M}$ for two different strains of $C$. trachomatis. $^{7}$ Some betulin derivatives showed high (>70\% growth inhibition) antichlamydial activity against $C$. pneumoniae at $1 \mu \mathrm{M}{ }^{8}{ }^{8}$ To the best of our knowledge, there is no data about the inhibition of Chlamydia trachomatis by triterpenoids and their derivatives.

\section{Experimental}

General: The spectra recorded at the Center for the Collective Use 'Chemistry' of the Ufa Institute of Chemistry of the UFRC RAS. ${ }^{1} \mathrm{H}$ and ${ }^{13} \mathrm{C}-\mathrm{NMR}$ spectra were recorded on a "Bruker AM-500" (Bruker, Billerica, MA, USA, 500 and $125.5 \mathrm{MHz}, \delta, \mathrm{ppm}, \mathrm{Hz}$ ) in $\mathrm{CDCl}_{3}$, internal standard tetramethylsilane. Mass spectra were obtained on a liquid chromatograph-mass spectrometer LCMS-2010 EV (Shimadzu, Kyoto, Japan). Melting points were detected on a micro table "Rapido PHMK05" (Nagema, Dresden, Germany). Optical rotations were measured on a polarimeter "Perkin-Elmer 241 MC" (PerkinElmer, Waltham, MA, USA) in a tube length of $1 \mathrm{dm}$. Elemental analysis was performed on a Euro EA-3000 CHNS analyzer (Eurovector, Milan, Italy); the main standard is acetanilide. Thin-layer chromatography analyses were performed on Sorbfil plates (Sorbpolimer, Krasnodar, Russian Federation), using the solvent system chloroform-ethyl acetate, $40: 1$. Substances were detected by a $10 \%$ solution of a sulfuric acid solution with subsequent heating at $100-120^{\circ} \mathrm{C}$ for $2-3 \mathrm{~min}$. Oleanolic and nicotinic acids were purchased from Sigma Aldrich.

Synthesis of 3 $\beta$-nicotinoyloxy-olean-12(13)-en-28-oic acid 1: A mixture of oleanolic acid (229 mg, $0.5 \mathrm{mmol}), \mathrm{N}, \mathrm{N}^{\prime}$-dicyclohexylcarbodiimide (103 mg, $\left.1 \mathrm{mmol}\right)$, DMAP (cat.) and nicotinic acid (160 mg, $1.3 \mathrm{mmol}$ ) in $\mathrm{CH}_{2} \mathrm{Cl}_{2}(15 \mathrm{~mL})$ was stirred for $6 \mathrm{~h}$ at $5{ }^{\circ} \mathrm{C}$, then poured into $5 \% \mathrm{HCl}$ solution $(50 \mathrm{~mL})$ and the precipitate was filtered off, washed with $\mathrm{H}_{2} \mathrm{O}$. The product was isolated by crystallization from ethanol with yield of $95 \%(267 \mathrm{mg})$ as beige powder. $\mathrm{R}_{f} 0.15$. M.p. $221^{\circ} \mathrm{C}$. $[\alpha]_{D}{ }^{20}+97\left(\mathrm{c} 0.5, \mathrm{CHCl}_{3}\right)$. [Lit. ${ }^{9}:$ M.p. $\left.220-222{ }^{\circ} \mathrm{C} .[\alpha]_{D}{ }^{20}+98\left(\mathrm{c} 0.5, \mathrm{CHCl}_{3}\right)\right] .{ }^{1} \mathrm{H} \mathrm{NMR}(\delta, \mathrm{ppm}$, $500 \mathrm{MHz}, \mathrm{CDCl}_{3}$ ): 9.20 (s, 1H, H-6'), 8.75 (d, $\left.J=4 \mathrm{~Hz}, 1 \mathrm{H}, \mathrm{H}-5^{\prime}\right), 8.30$ (d, $\left.J=10,1 \mathrm{H}, \mathrm{H}-3^{\prime}\right), 7.39$ (t, $J=5 \mathrm{~Hz}, 1 \mathrm{H}, \mathrm{H}-4$ ) $, 5.30(\mathrm{~s}, 1 \mathrm{H}, \mathrm{H}-12), 4.75$ (t, $J=3.8 \mathrm{~Hz}, 1 \mathrm{H}, \mathrm{H}-3), 2.85$ (t, $J=3.8 \mathrm{~Hz}, 1 \mathrm{H}, \mathrm{H}-$ 18), 2.00-1.20 (m, 22H), $1.15(\mathrm{~s}, 3 \mathrm{H}), 1.05(\mathrm{~s}, 3 \mathrm{H}), 1.00(\mathrm{~s}, 3 \mathrm{H}), 0.98(\mathrm{~s}, 3 \mathrm{H}), 0.90(\mathrm{~s}, 3 \mathrm{H}), 0.88(\mathrm{~s}$, $3 \mathrm{H}), 0.80(\mathrm{~s}, 3 \mathrm{H}) .{ }^{13} \mathrm{C}$ NMR $\left(\delta, \mathrm{ppm}, 125.5 \mathrm{MHz}, \mathrm{CDCl}_{3}\right)$ : $183.6(\mathrm{C}-28), 164.9\left(\mathrm{C}-1^{\prime}\right), 152.9(\mathrm{C}-6)$, 150.6 (C-5'), 143.8 (C-13), 137.3 (C-3'), 126.9 (C-2'), 123.4 (C-4'), 122.4 (C-12), 82.4 (C-3), 55.4, 54.8, 47.6, 46.5, 45.9, 41.6, 40.9, 39.3, 38.1, 37.0, 34.6, 33.8, 33.1, 32.6, 32.5, 30.7, 28.2, 27.7, 25.9, 23.6, 23.4, 22.9, 18.2, 17.2, 16.9, 15.4 Anal. calc. for $\mathrm{C}_{36} \mathrm{H}_{51} \mathrm{NO}_{4}$ : C, 76.97; H, 9.15; N, 2.49 . Found: C, 76.89; H, 9.13; N, 2.52. MS(APCI): $m / z$ 562.78 $[M+\mathrm{H}]^{+}$, (calcd. 561.81).

Synthesis of 3-deoxy-3a-homo-3a-aza-28-hydroxy-olean-12(13)-ene 3. A mixture of compound $2^{10}$ (235 mg, $0.5 \mathrm{mmol})$ and $\mathrm{LiAlH}_{4}(19 \mathrm{mg}, 0.5 \mathrm{mmol})$ in anhydrous THF was refluxed for $30 \mathrm{~min}$ and then poured into a $5 \% \mathrm{HCl}$ solution $(70 \mathrm{~mL})$. The crude product was extracted with $\mathrm{CHCl}_{3}(3 \times 50)$, the organic layer was washed with $\mathrm{H}_{2} \mathrm{O}$, dried under $\mathrm{CaCl}_{2}$ and evaporated in vacuo. The product was isolated by crystallization from ethanol with yield of $88 \%(194 \mathrm{mg}) \mathrm{R}_{f} 0.11$. M.p. $174{ }^{\circ} \mathrm{C}$. $[\alpha]_{D}{ }^{20}+2\left(\mathrm{c} 0.5, \mathrm{CHCl}_{3}\right)$. [Lit. ${ }^{11}:$ M.p. $\left.175{ }^{\circ} \mathrm{C} .[\alpha]_{D}{ }^{20}+1.7\left(\mathrm{c} 0.5, \mathrm{CHCl}_{3}\right)\right] .{ }^{1} \mathrm{H}$ NMR $(\delta, \mathrm{ppm}, 500$ 
$\mathrm{MHz}, \mathrm{CDCl}_{3}$ ): 5.20 (s, 1H, H-12), 3.50 and 3.28 (both d, $\left.J=10.8 \mathrm{~Hz} 2 \mathrm{H}, \mathrm{H}-28\right), 3.00-2.92(\mathrm{~m}, 2 \mathrm{H}$, H-3), 2.05-1.52 (m, 25H), 1.50 (s, 3H), 1.41 (s, 3H), 1.20 (s, 3H), 1.15 (s, 3H), $1.00(\mathrm{~s}, 3 \mathrm{H}), 0.88$ $(\mathrm{s}, 3 \mathrm{H}), 0.85$ (s, 3H). ${ }^{13} \mathrm{C}$ NMR $\left(\delta, \mathrm{ppm}, 125.5 \mathrm{MHz}, \mathrm{CDCl}_{3}\right): 143.8(\mathrm{C}-13), 122.7$ (C-12), 69.5 (C28), 62.3 (C-3), 54.6 (C-5), 46.2, 44.2, 42.5, 42.4, 41.1, 40.9, 40.1, 39.6, 37.0, 34.1, 33.2, 32.3, $31.0,30.9,28.3,25.4,25.3,24.3,23.7,23.6,22.3,22.1,22.0,17.2,16.6$. Anal. calc. for $\mathrm{C}_{30} \mathrm{H}_{51} \mathrm{NO}$ : C, 81.57; H, 11.64; N, 3.17. Found: C, 81.49; H, 11.51; N, 3.11. MS(APCI): $m / z 442.64[M+\mathrm{H}]^{+}$, (calcd. 441.74).

Reagents and organisms: Strain C. trachomatis F-3271/Belarus/2015 specialized collection of viruses and bacteria pathogenic for humans http://www.belriem.by/about/collection (Research Center for Epidemiology and Microbiology, Minsk, Belarus) were used. Sequencing of the ompA gene using primers P1/OMP2, NL-F/NL-R, CT6F/OMP2, P1/CT6R ${ }^{12}$ showed that this strain corresponds to the serovar $\mathrm{F}$ and has $100 \%$ homology with the sequence of the strain F/IC-CAL3 https://www.ncbi.nlm.nih.gov/nuccore/DQ064287.1. The nucleotide sequence of the ompA gene of strain C. trachomatis F-3271/Belarus/2015 is deposited in the GenBank database https://www.ncbi.nlm.nih.gov/nuccore/MG733343.

Cell Culture: C. trachomatis were propagated in McCoy cells grown in DMEM with $10 \%$ heatinactivated fetal bovine serum (HyClone, USA) supplemented with $2 \mathrm{mM} \mathrm{L}$-glutamine, $10 \mu \mathrm{g} / \mathrm{mL}$ gentamicin, $5 \mathrm{mg} / \mathrm{mL}$ amphotericin B and $1 \mu \mathrm{g} / \mathrm{mL}$ cycloheximide (AppliChem, Germany). McCoy cells were cultured in glass flasks for $72 \mathrm{~h}$. The cells were suspended after the addition of $0.02 \%$ ethylenediamine tetraacetate (Lonza, USA). $1 \mathrm{~mL}$ of the cell suspension, containing $10^{5}$ cells, was transferred to flat-bottomed plastic tubes containing a coverslip (13 $\mathrm{mm}$ in diameter). The cells were incubated at $37{ }^{\circ} \mathrm{C}$ for $24 \mathrm{~h}$ to obtain a confluent cell layer. Then $80-90 \%$ confluent McCoy cell monolayer was infected stock suspension of $C$. trachomatis at a multiplicity rate of $1: 1$. The plate was centrifuged for $1 \mathrm{~h}$ at $1500 \mathrm{x} \mathrm{g}$ (relative centrifugal force) to synchronize the infection. After centrifugation, the tubes were incubated for $2 \mathrm{~h}$ at $37{ }^{\circ} \mathrm{C}$, and thereafter a wide range of concentrations of compounds 1, 3-5 additions to the culture medium was performed. Tested compounds were preliminarily dissolved in $10 \%$ ethanol. Each test was performed in triplicate. All experiments were supplemented with negative (intact McCoy cells) and positive controls (McCoy cells infected by strain C. trachomatis). As quantitative criteria of the observable antichlamydial action, a decrease in the titer $C$. trachomatis was calculated in comparison with the control, TCID ${ }_{50}$ (Median Tissue Culture Infectious Dose) of the compounds and chemotherapeutic index (CTI) were determined.

Assessment of Infective Progeny: The infection rate in the McCoy cells and infective progeny formation were estimated $72 \mathrm{~h}$ after pathogen inoculation. Titers were determined by infecting cell monolayers with 10-fold dilutions of the thawed stock suspension. All monolayers were stained using FITC-conjugated monoclonal antibody against chlamydial lipopolysaccharide (NearMedic Plus, Russian Federation). Inclusion-containing cells were visualized using the Nikon Eclipse 50i microscope at $\mathrm{x} 1000$ magnification.

\section{Present Study}

The aim of this study was to suggest the most convenient synthesis of two oleanane triterpenoids $\mathbf{1}$ and $\mathbf{3}$ from natural occurring oleanolic acid. It was shown that $3 \beta$-nicotinoyloxyolean-12(13)-en-28-oic acid 1 inhibited the influenza type A H1N1 and the papillomavirus HPV$11^{9}$ and 3-deoxy-3a-homo-3a-aza-28-hydroxy-olean-12(13)-en $\mathbf{3}$ showed activity against $M$. tuberculosis. ${ }^{11}$ Environmentally friendly and economical synthesis of drugs and biologically active agents is one of the important aspects for the pharmaceutical industry, which is achieved by reducing the number of stages, using non-toxic solvents, etc. For this purpose, we acylated oleanolic acid by nicotinic acid in $\mathrm{CH}_{2} \mathrm{Cl}_{2}$ using as a dehydrating agent DCC and a catalytic amount DMAP with the formation of acylate 1 with a yield of $95 \%$ after crystallization from 
Synthesis and in vitro activity of oleanane type derivatives

ethanol (Scheme 1). Previously this compound was synthesized by a two-step way using preliminary obtained nicotinic acid chloride with the following reaction with oleanolic acid in pyridine. ${ }^{9}$ Thus, we reduced the number of stages from two to one, explored nontoxic reagents and increased the yield of target compound $\mathbf{1}$ by $10 \%$. The synthesis of compound $\mathbf{3}$ was modified in comparison with the earlier described method ${ }^{11}$ by reducing of the number of stages (from 5 to 4 ) and, respectively, by increasing the total yield. We have excluded the stage of protecting the $\mathrm{COOH}$-group of oleanolic acid by methylation as described in $^{11}$ and used A-azepanono-oleanolic acid $\mathbf{2}^{10}$ as a starting material to obtain azepane $\mathbf{3}$.

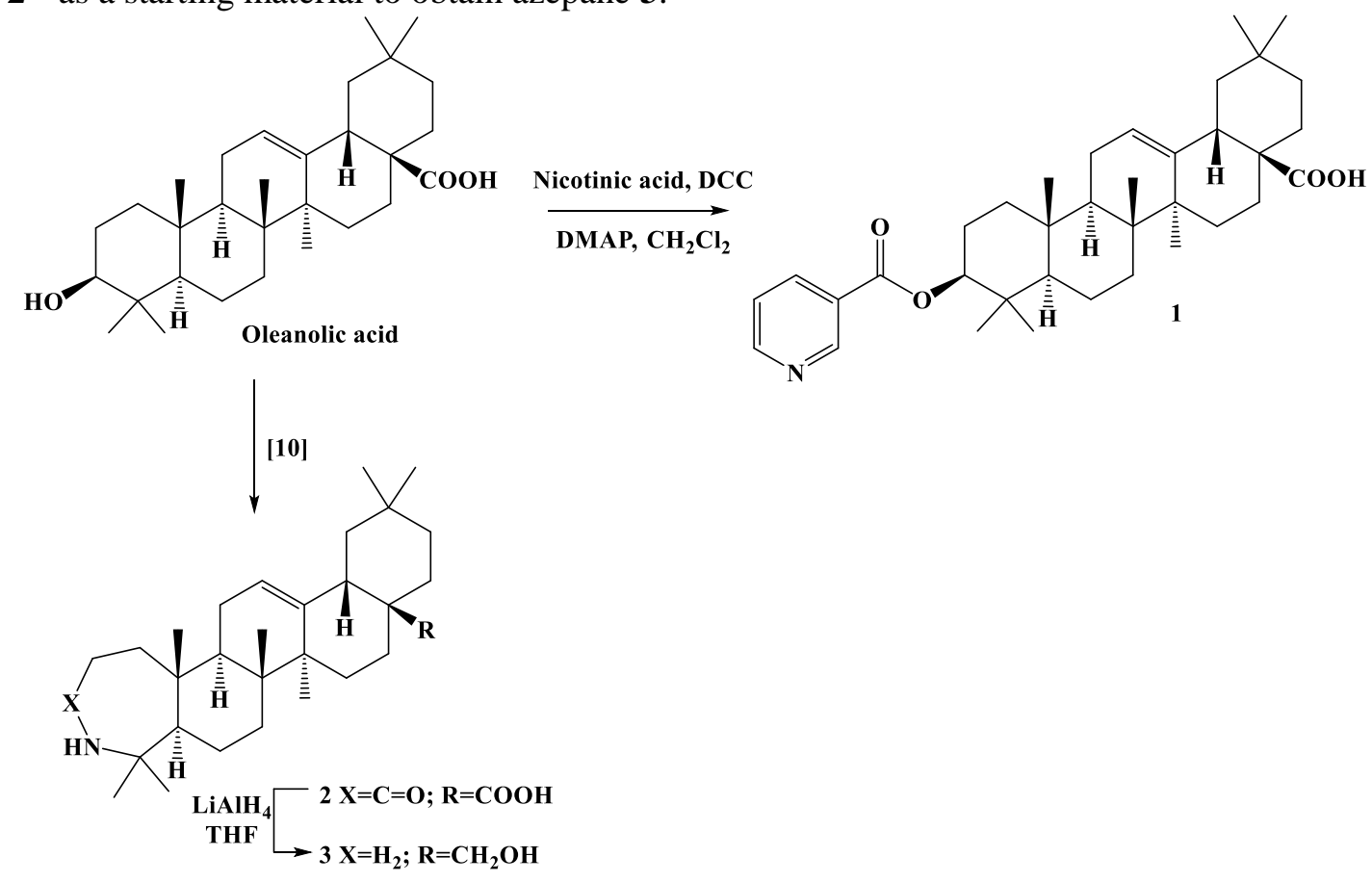

Scheme 1. Synthesis of oleanane type triterpenoid derivatives

The second aim of this research was to evaluate the potential of triterpenoid derivatives against $C$. trachomatis. We decided to take the compounds, which have already shown any antiinfective activity (antiviral ${ }^{9}$ for compound $\mathbf{1}$, antitubercular ${ }^{11}$ for compounds $\mathbf{3}, \mathbf{5}$ and antimalarial ${ }^{13}$ for compound 4) (Figure 1).

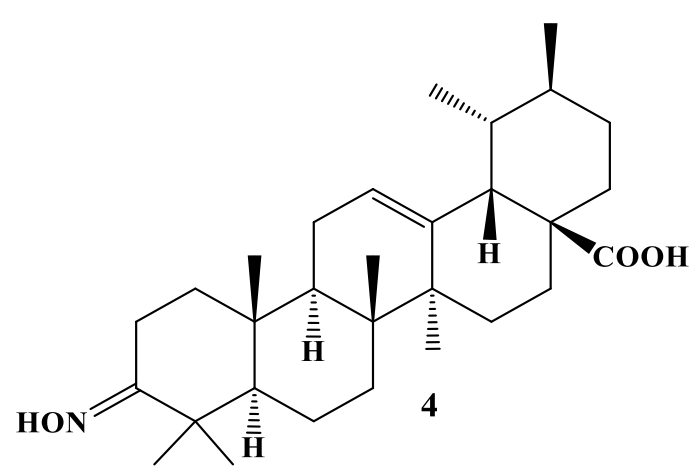

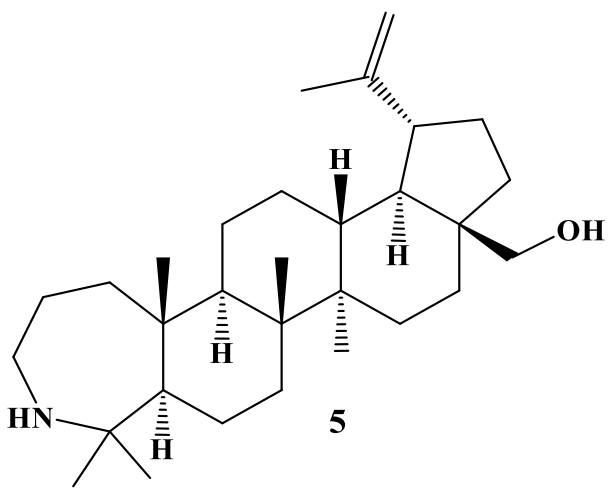

Figure 1. Synthetic derivatives of ursane 4 and lupane 5 type

Compounds 1, 3-5 were screened in vitro toward Chlamydia trachomatis strain F3271/Belarus/2015. TCID 50 assay method to determine the viability of Chlamydia under compounds action was used. The degree of the pathogen sensitivity to tested compounds was determined on the basis of the chemotherapeutic index (CTI) (Table 1). It was revealed that triterpenoids showed different potential. Compounds $\mathbf{1}$ and $\mathbf{3}$ demonstrated a high Chlamydia inhibitory activity (chemotherapeutic index was $>8$ ). The range of active non-toxic concentrations 
Kazakova et al., Org. Commun. (2019) 12:3 169-175

for compounds $\mathbf{1}$ and $\mathbf{3}$ is quite wide (the lower limit is not reached). The minimum active concentration of compound 4 that reduces the Chlamydia titer by at least $1.251 \mathrm{~g}$ was less than 100 $\mu \mathrm{g} / \mathrm{mL}$. Azepanobetulin $\mathbf{5}$ has a chemotherapeutic index of 2 and was classified as low active.

\section{Conclusion}

As a result of this screening study oleanane type derivatives $\mathbf{1}$ and $\mathbf{3}$ were found to be promising for further research and we have developed the most convenient synthesis of these biologically active triterpenoids.

Table 1. An activity of compounds 1, 3-5 against Chlamydia trachomatis in McCoy cells test

\begin{tabular}{|c|c|c|c|c|}
\hline Compound & $\begin{array}{c}\text { Concentration, } \\
\mu \mathrm{g} / \mathrm{mL}\end{array}$ & $\begin{array}{l}\text { Titer strain, } \\
\lg _{\text {TCID }}\end{array}$ & $\begin{array}{l}\text { Difference with } \\
\text { positive control, } \\
\lg \text { TCID }_{50}\end{array}$ & $\begin{array}{l}\text { Chemotherapeutic } \\
\text { index (CTI) }\end{array}$ \\
\hline \multirow{8}{*}{1} & 800 & $<2$ & $>3.8$ & \multirow{8}{*}{$>8$} \\
\hline & 400 & $<2$ & $>3.8$ & \\
\hline & 200 & $<2$ & $>3.8$ & \\
\hline & 100 & $<2$ & $>3.8$ & \\
\hline & 50 & $<2$ & $>3.8$ & \\
\hline & 25 & $<2$ & $>3.8$ & \\
\hline & 12.5 & $<2$ & $>3.8$ & \\
\hline & 6.25 & $<2$ & $>3.8$ & \\
\hline \multirow{8}{*}{3} & 800 & $<2$ & $>3.8$ & \multirow{8}{*}{$>8$} \\
\hline & 400 & $<2$ & $>3.8$ & \\
\hline & 200 & $<2$ & $>3.8$ & \\
\hline & 100 & $<2$ & $>3.8$ & \\
\hline & 50 & $<2$ & $>3.8$ & \\
\hline & 25 & $<2$ & $>3.8$ & \\
\hline & 12.5 & $<2$ & $>3.8$ & \\
\hline & 6.25 & $2.20 \pm 0.07$ & 3.6 & \\
\hline \multirow{8}{*}{4} & 800 & $<2$ & $>3.8$ & \multirow{8}{*}{8} \\
\hline & 400 & $<2$ & $>3.8$ & \\
\hline & 200 & $<2$ & $>3.8$ & \\
\hline & 100 & $<2$ & $>3.8$ & \\
\hline & 50 & $4.70 \pm 0.05$ & 1.1 & \\
\hline & 25 & $5.60 \pm 0.08$ & 0.2 & \\
\hline & 12.5 & $5.8 \pm 0.1$ & 0 & \\
\hline & 6.25 & $5.8 \pm 0.1$ & 0 & \\
\hline \multirow{8}{*}{5} & 800 & $<2$ & $>3.8$ & \multirow{8}{*}{2} \\
\hline & 400 & $3.6 \pm 0.2$ & 2.2 & \\
\hline & 200 & $5.8 \pm 0.1$ & 0 & \\
\hline & 100 & $5.8 \pm 0.1$ & 0 & \\
\hline & 50 & $4.90 \pm 0.15$ & 0.9 & \\
\hline & 25 & $5.8 \pm 0.1$ & 0 & \\
\hline & 12.5 & $5.10 \pm 0.07$ & 0.7 & \\
\hline & 6.25 & $5.8 \pm 0.1$ & 0 & \\
\hline $\begin{array}{l}\text { Positive } \\
\text { control }\end{array}$ & $\begin{array}{l}\text { Culture cells } \\
\text { infected with strain } \\
\text { C. trachomatis CT- } \\
\text { 3271/Belarus/2015 }\end{array}$ & $5.8 \pm 0.1$ & - & \\
\hline
\end{tabular}


Synthesis and in vitro activity of oleanane type derivatives

\section{Acknowledgements}

This work was supported by the State task projects no. AAAA-A17-117011910023-2 and AAAA-A19-119020890014-7.

\section{Supporting Information}

Supporting information accompanies this paper on http://www.acgpubs.org/journal/organiccommunications

\section{ORCID}

Oxana B. Kazakova 0000-0002-5606-1588

Liudmila V. Rubanik: 0000-0002-7963-0026

Irina E. Smirnova 0000-0001-7176-505X

Olga V. Savinova 0000-0002-1835-7724

Anastasiya V. Petrova 0000-0003-2910-6805

Nikolay N. Poleschuk 0000-0003-1083-6680

Elmira F. Khusnutdinova 0000-0001-6769-6063

Eugene I. Boreko 0000-0001-9158-298X

Yuliya M. Kapustsina 0000-0002-6400-7186

\section{References}

[1] Bouberte, M.Y.; Krohn, K.; Hussain, H.; Dongo, E.; Schulz, B.; Hu, Q. Tithoniamarin and Tithoniamide: A new isocoumarin dimer and a new ceramide from Tithnonia diversifolia. Nat. Prod. Lett. 2006, 20, 842-849.

[2] Bouberte, M.Y.; Krohn, K.; Hussain, H.; Dongo, E.; Schulz, B.; Hu, Q. Tithoniaquinone a and Tithoniamide B: A new anthraquinone and a new ceramide from the leaves of Tithnonia diversifolia. $Z$. Naturforsch. 2006, 61B, 78-82.

[3] Barret, J.P.; Podmelle, F.; Lipový, B.; Rennekampff, H.O.; Schumann, H.; Schwieger-Briel, A.; Zahn, T.R.; Metelmann, H.R. Accelerated re-epithelialization of partial-thickness skin wounds by a topical betulin gel: results of a randomized phase III clinical trials program. Burns. 2017, 43, 1284-1294.

[4] a) Cunha, W.R.; Matos, G.X.; Souza, M.G.; Tozatti, M.G.; Silva, M.L.A.; Martins, C.H.; Silva, R.; Da Silva Filho, A.A. Evaluation of the antibacterial activity of the methylene chloride extract of Miconia ligustroides, isolated triterpene acids, and ursolic acid derivatives. Pharm. Biol. 2009, 48, 166-169.

b) Catteau, G.L.; Zhu, L.; Bambeke, F.V.; Quetin-Leclercq, J. Natural and hemi-synthetic pentacyclic triterpenes as antimicrobials and resistance modifying agents against Staphylococcus aureus: a review. Phytochem. Rev. 2018, 17, 1129-1163.

[5] a) Tazooa, D.; Krohn, K,; Hussain, H.; Kouam, S.F.; Dongoa, E. Laportoside A and laportomide A: A new cerebroside and a new ceramide from Leaves of Laportea ovalifolia. Z. Naturforsch. 2007, 62B, 1208-1212. b) Antoine, K.Z.; Hussain, H.; Dongo, E.; Kouam, S.F.; Schulz, B.; Krohn, K. Cameroonemide A: A new ceramide from Helichrysum cameroonensei. J. Asian Nat. Prod. Res. 2010, 12, 629-633.

[6] Eyong, K.O.; Krohn, K.; Hussain, H.; Folefoc, G.N.; Nkengfack, A.E.; Schulz B.; Hu, Q. Newbouldiaquinone and Newbouldiamide: A new naphthoquinone-anthraquinone coupled pigment and a new ceramide from Newbouldia laevis. Chem. Pharm. Bull. 2005, 53, 616-619.

[7] Hua, Z.; Frohlich, K.M.; Zhang, Y.; Feng, X.; Zhang, J.; Shen, L. Andrographolide inhibits intracellular Chlamydia trachomatis multiplication and reduces secretion of proinflammatory mediators produced by human epithelial cells. FEMS Pat. Dis. 2015, 73, 1-11.

[8] Salin, O.; Alakurtti, S.; Pohjala, L.; Siiskonen, A.; Maass, V.; Maass, M.; Yli-Kauhaluoma, J.; Vuorela, P. Inhibitory effect of the natural product betulin and its derivatives against the intracellular bacterium Chlamydia pneumonia. Biochem. Pharmacol. 2010, 80, 1141-1151.

[9] Kazakova, O.B.; Medvedeva, N.I.; Baikova, I.P.; Tolstikov, G.A.; Lopatina, T.V.; Yunusov, M.S.; Zaprutko L. Synthesis of triterpenoid acylates - an effective reproduction inhibitors of influenza A (H1N1) and papilloma viruses. Russ. J. Bioorg. Chem. 2010, 36, 841-848. 
Kazakova et al., Org. Commun. (2019) 12:3 169-175

[10] Finlay, H.J.; Honda, T.; Gribble, G.W.; Danielpour, D.; Benoit, N.E.; Suh, N.; Williams, C.; Sporn, M.B. Novel A-ring cleaved analogs of oleanolic and ursolic acids which affect growth regulation in NRP.152 prostate cells. Bioorg. Med. Chem. Lett. 1997, 7, 1769-1772.

[11] Medvedeva, N.I.; Kazakova, O.B.; Lopatina, T.V.; Smirnova, I.E.; Giniyatullina, G.V.; Baikova, I.P.; Kataev, V.E. Synthesis and antimycobacterial activity of triterpenic A-ring azepanes. Eur. J. Med. Chem. 2018, 143, 464-472.

[12] Jurstrand, M.; Falk, L.; Fredlund, H.; Lindberg, M.; Olcen, P.; Andersson, S.; Persson, K.; Albert, J.; Backman, A. Characterization of Chlamydia trachomatis omp1 genotypes among sexually transmitted disease patients in Sweden. J. Clin. Microbiol. 2001, 39, 3915-3919.

[13] Dalla-Vechia, L.; Dassonville-Klimpt, A.; Grellier, P.; Sonnet, P.; Gosmann, G.; Gnoatto, S.C.B. The Beckmann rearrangement applied to ursolic acid with antimalarial activity in medicinal chemistry studies. Lett. Org. Chem. 2012, 9, 92-95.

\section{A C G \\ publications}

(C) 2019 ACG Publications 